\title{
第50回 日本視能矯正学会
}

\section{シンポジウム}

\section{「本音で語ろう間欠性外斜視」 \\ 片眼後転短縮術}

\author{
初川嘉一 \\ 大阪府立母子保健総合医療センター眼科

\section{unilateral recession-resection surgery}

\section{Yoshikazu Hatsukawa}

Eye Department, Osaka Medical Center and Research Institute for Maternal and Child Health

\begin{abstract}
要 約
間欠性外斜視は最も頻度の高い斜視であるが、眼位の矯正が難しい斜視である。外斜視に対する 片眼後転短縮術の多施設共同研究では、初回の手術により最終眼位が $15 \Delta$ 以に治瘾したのは383例 中264例 $(68.9 \%)$ であった。治療成績に影響する因子を多変量logistic回帰分析で検討した結果、術 前眼位 $30 \Delta$ 未満、術後 1 週の眼位が内斜位の場合に治癒率が高かった。Adlerによる斜視の病因論 を紹介し、その妥当性を解説した。課題症例への対応を述べた。
\end{abstract}

J-STAGE早期公開日：2010年 9 月17日

別冊請求先（５594-1101）和泉市室堂町840

大阪府立母子保健総合医療センター眼科 初川嘉一

Tel. 0725（56） 1220 Fax. 0725（56） 5682

E-mail : hatsu@mch.pref.osaka.jp

Key words：間欠性外斜視、多施設研究、多変量解析、病因論

intermittent exotropia, multicenter study, multivariate logistic analysis, etiology 


\begin{abstract}
Intermittent exotropia is most frequently seen in strabismus, but, it is very difficult type for treatment. According to the multicenter study on unilateral recession-resection surgery for exotropia, 264 cases among 383 exotropes (68.9\%) were successfully treated with the final deviation of 15 prism diopters or less. We studied on some factors affecting for the surgical result using multivariate logistic analysis, and preoperative deviation of less than 30 prism diopters and small esophoria-tropia at one week postoperative time were elucidated significantly contributing to the success rate. Etiology of strabismus by Dr. Adler was introduced and its reliability was explained. Treatments for the presented cases were discussed.
\end{abstract}

\section{I 。はじめに}

間欠性外斜視は東洋人では最も頻度の高い斜 視である。通常、視力、両眼視機能に異常がな く、問題となるのは外見に対するコンプレック ス、眼精疲労、複視である。筆者は眼科医であ るので、これらの問題に対して外科的手術で治 療してきた。すなわち、眼位の手術による矯正 で、外見を改善するとともに、眼精疲労や複視 による悩みも改善されると考えているので、手 術による治療成績と治療の根拠について述べて みたい。

\section{II. 片眼後転短縮術の多施設共同研究}

日本弱視斜視学会では、間欠性外斜視に対す る片眼後転短縮術の治療成績について、6 施設 での共同研究を行った。参加施設は大阪医科大 学、大阪大学、国立成育医療センター、兵庫医 科大学、矢ケ崎眼科、大阪府立母子保健総合医 療センターである。

a. 対象

手術時年齢 $4 \sim 12$ 歳の間欠性外斜視で、 片眼後転短縮術後 3 年以上の経過観察を 行えた計383症例を対象とした。

b . 検討方法

術後 3 年での最終眼位が $15 \Delta$ 以下の間欠 性外斜視または $10 \Delta$ 以下の内斜位（間欠 性内斜視）のものを治癒とした。検討因 子として、術前眼位、手術時年齢、外斜 視の型（基礎型、輻湊不全型、開散過多 型、みかけの開散過多型)、術後 1 週で の眼位とし、治癒率との関係について統
計学的に検討した。

c. 結果

i ．治療成績：治癒した症例は、施設に より 44 75\%であり、全383例中 264 例 $(68.9 \%)$ であった。

ii . 治癒に影響する因子：施設間、術者 間の違いによる影響を除くために、 多変量logistic回帰分析を用いて検討 した。術前眼位 $30 \Delta$ 未満は $30 \Delta$ 以上 より有意に治癒率が高く、術後 1 週 での眼位が内斜視（過矯正）は、正 位または外斜視に比べて有意に治癒 率が高かった（表 1 ）。Odds比で 2 に近い值となっているが、薬効に置 き換えると 2 倍有効ということであ り、圧倒的に有効であることが明ら かになった（表 2)。

iii. その他の因子：斜視の型、術前眼位 が40 $\Delta$ 未満とそれ以上、手術時年齢 が 4 〜 歳と 9 〜 12 歳などでの比較 では治癒率に有意な差は認められな かった。

表 1 術後 1 週間の眼位と治癒

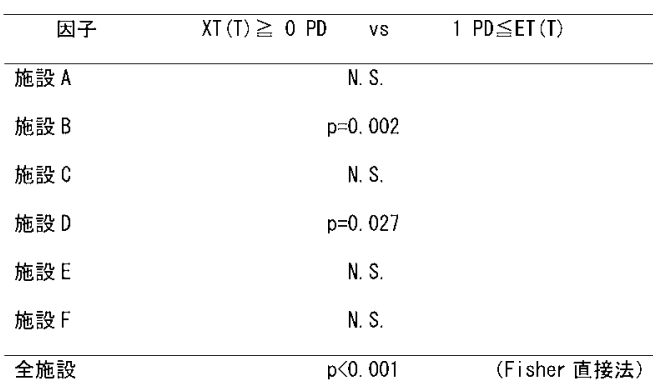


表 2 治癒に影響する因子（施設調整後）

\begin{tabular}{|c|c|c|}
\hline 因子 & Odds 比 $\quad(95 \%$ C. I， $)$ & p 值 \\
\hline 術前眼位 30 $\Delta$ 未满 & $1.97(1.20,3.22)$ & $p=0.007$ \\
\hline 術前眼位 $40 \triangle$ 未満 & & N. S. \\
\hline 手術年路 9 12 歳 & & N. S. \\
\hline 術後 1 週 $E T(T)$ & 2. $48(1.45,4.22)$ & $p=0.001$ \\
\hline 術後 1 週 11 $\Delta \sim \mathrm{ET}(\mathrm{T})$ & 1. $90(1.11,3.26)$ & $p=0.020$ \\
\hline
\end{tabular}

(多変量 Logist ic 回帰分析)

\section{d. 中間的総括}

現時点での多施設研究の結果をまとめる と、術前眼位 $30 \Delta$ 未満、術後 1 週の眼位 が内斜位（過矯正）の場合に治癒率が高 いことがわかった。

\section{III. 斜視の病因論}

間欠性外斜視の治療では手術によっても戻り が問題になるし、輻湊訓練でも治療の限界があ る。これまでの治療の壁を打ち破るには、本質 的な病因論に立ち返って考える必要がある。こ れまで斜視に関する偉大な研究書は少なくなく、 どの本にも斜視の特徵については詳しく書かれ ているが、残念ながら斜視の病因論については 驚くほどわずかの記載にとどまっている11。

歴史上は1903年のClaud Worthによる融像欠 陷論が提出された時期があった。自らが開発し たアーム式の大型弱視鏡により斜視患者の融像 の異常を発見したと思われるが、この説は1939 年のChavasseが改訂したWorth's Squint第 7 版 ${ }^{2)}$ の中で、融像の欠如は数日の練習で正常化 すると書かれており、はっきりと否定されてい る。われわれの経験でも、間欠性外斜視におい て両眼視機能の異常が原因と考えることは難し い。また、ほとんどの内斜視で同時視、融像が 確認される。現在では、Worthの説、すなわち 融像の欠如が斜視のprimaryの原因であるとす る説は顧みられなくなっており、斜視にみられ る両眼視機能の異常は斜視の原因ではなく結果 ということになる。

つぎに、有名な説としては、オランダの Keinerによるoptomotor の異常説 ${ }^{3)}$ がある。 Optomotor reflexというのは、通常の生理学書
には記載のない眼科独特の表現で、後頭葉皮質 を介した半ば意識的、なかば無意識的な反射、 または反応とでも呼ぶべき現象である。 Keiner は暗室で耳側網膜へ光刺激を与えると眼球の内 転を誘発することを多数例で発見し、この現象 が主にproprioception由来の反射の異常による もので、それが内斜視の原因であると彼の 222 頁 の本の中で繰り返し説明されているが、どうし てその一つの現象だけで内斜視の発生に結びつ くのか、またproprioceptionと結びつくのか、科 学書とするには余りにも観念的で難解な書物と なっている。最近ではoptokinetic nystagmusに 注目したTychsenらの研究 ${ }^{4)}$ があるが、これも 同様の説明のように思われて理解しにくいもの である。Keinerの研究はわが国ではMitsui ${ }^{5)} ら$ が筋電図を用いて発展させた。

斜視の病因論として特筆すべきものにFrancis Adlerの1953年の論文 ${ }^{6)}$ を紹介したい。国の内 外で必ずしも広く知れ渡っていないが、斜視を 理解する上で非常に貴重な論文である。Adler は眼生理学のバイブルとされた「Physiology of the Eye」の著者である。一般的に斜視は中枢 の異常と漠然と考えられているが、Adlerは斜 視を内斜視、外斜視のような共同性斜視と上下 斜視や下斜筋過動症のような非共同性斜視に分 け、共同性斜視は核上性の異常、非共同性斜視 は核、核下性、筋肉の異常と説明している。こ の論文の中で、開散時にも筋電図上で外直筋の 放電がみられることから、輻湊のみならず開散 も activeに行われていること、眼位は輻湊系と 開散系へのinnervationの量で決定されると考え ている。Adlerによると、通常、外直筋には常 時、VOR、stretch reflex、proprioception、 tonic convergenceなどからの信号が働いている こと、また、皮質中枢にはoptomotor reflex と して固視、追視、融像、調節の信号が入力され ており、輻湊系と開散系のinnervationが均衡し ていると正位となる。外斜視では先天的に何ら かの過剩な刺激が開散系に働いて外斜視の眼位 になると説明している（図1、図2）。 Jampolsky $^{\text {7) }}$ やMitsuiらの研究で確認された筋 電図での過剩な興奮状態は、この説に従うと開 散系への異常な信号をとらえていたと考えられ 


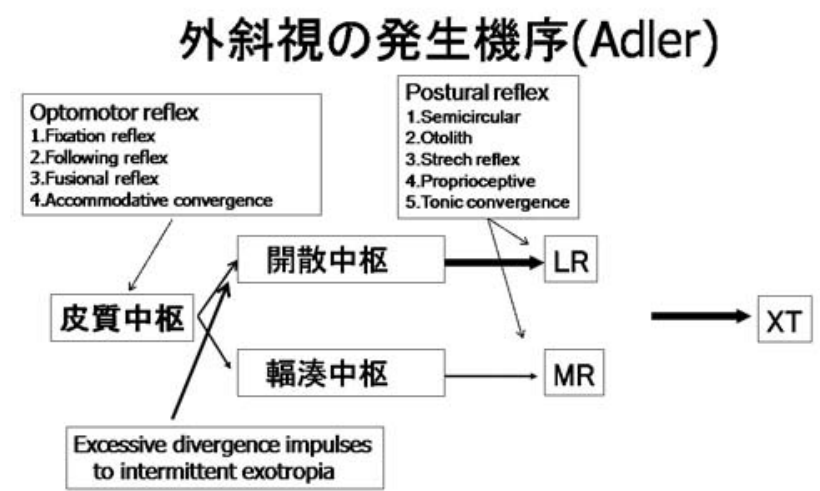

図 1 Adler FHの説による外斜視の発生機序の模式図（文献 ${ }^{6)}$ を筆者がまとめたもの）

\section{内斜視の発生機序(Adler)}

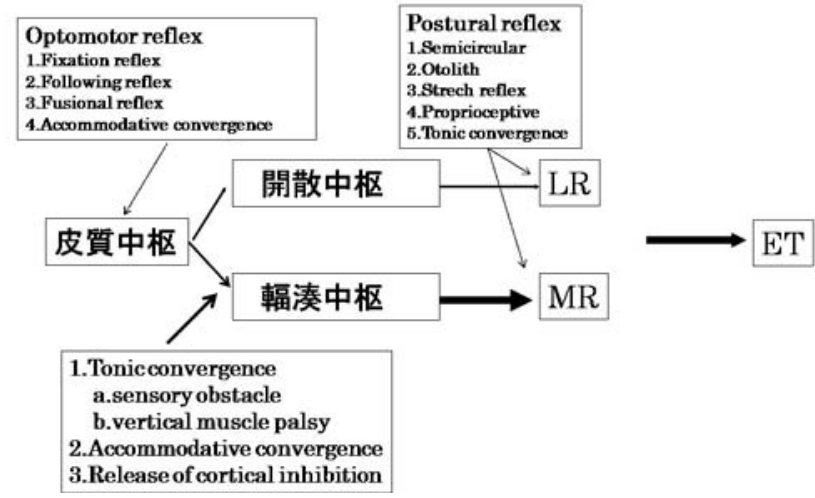

図 2 Adler FHの説による内斜視の発生機序の模式図（文献 ${ }^{6)}$ を筆者がまとめたもの）

る。このように考えると、共同性斜視では生ま れもった体質とでも呼ぶべき中枢の異常に対し て、末梢の外眼筋のみを操作して眼位を矯正し ていることになり、治療上の限界が生じるのは 仕方がないものと考えられる。また、下斜筋過 動症を始めとして上下斜視では術後の眼位が安 定していることも、Adlerの説を理解しやすい ものとしている。外斜視の手術では、後転短縮 術や後転術のそれぞれの術後経過の特徴に注意 しながら、手術の量定などの方針を決定するの がよさそうである。

\section{N．課題症例に対する治療}

症例 $1 ： 35$ 歳の男性でコンピュータープログ ラマー。主訴は眼精疲労である。屈折異常は右
$-0.5 \mathrm{D}$ 、左 $-0.5 \mathrm{D}$ の近視、斜視角は遠見 $20 \Delta \mathrm{X}$ $(\mathrm{T}) 、$ 近見 $35 \Delta \mathrm{X}(\mathrm{T})^{\prime}$ である。

斜視手術の目的はvon Noordenの言葉 ${ }^{8)}$ を借 りるまでもなく、快適な両眼単一視と整容であ るが、この症例の治療目的は前者が主となる。 手術では過矯正を避けるような手術を行う。

ここで注意したいことは、快適な両眼単一視 とは必ずしも正常両眼視機能を意味していない ことである。抑制や網膜異常対応の方が本人に とって快適な場合は少なくない。斜視を治した 方が本人に苦痛を与えることになるのは網膜異 常対応だけに限らないと思われ、そのようなこ とを判断するのが斜視の専門家の役割であろう。

症例 $2 ： 7$ 歳の女児で小学生。主訴は友人に 斜視を指摘され困っており、親はできれば手術 をしたくないとのことである。屈折異常は右0D、 
左 $-2 \mathrm{D}$ の近視、斜視角は遠見 $40 \Delta \mathrm{X}(\mathrm{T})$ 、近見 $25 \Delta \mathrm{X}(\mathrm{T})$ ' である。

この症例は整容により外見上のコンプレック スを取り除くことが治療目的である。この年齢 では過矯正による眼精疲労は生じにくいので、 最終眼位を良好とするために後転短縮術なら通 常はやや過矯正だが、（見かけ上の）開散過多 型のようであるので、あまり戻りが強くないこ とから必ずしも過矯正でなくてもよい。両側外 直筋の後転術なら正位狙いの手術を行い、術後 は強い戻りの予防のため眼鏡で近視と不同視を 矯正する。

\section{V. おわりに}

間欠性外斜視は内斜視のように弱視や両眼視 機能の異常に悩まされることがなく、眼位の異 常のみという単純な疾患である。しかしながら、 単純に眼位の矯正を続ける中で、斜視治療の本 質的な部分を実感してきた。また、今後の斜視 治療において解決されなければならない問題も まだまだ残されているようである。

\section{参考文献}

1) 初川嘉一：最近の斜視手術と今後の課題. 日
本視能訓練士協会誌 $38 ： 1-9,2009$.

2 ) Chavasse FB: Worth's theory. In Worth's Squint $7^{\text {th }}$ ed. 289-294, Balliere Tindal and Cox, London, 1939.

3 ) Keiner GBJ : New view points on the origin of squint. 61-201, Martinus Nijhoff, Hague, 1951.

4) Tychsen L : Motion sensitivity and the origin of infantile strabismus. In Simons K ed: Early Visual Development Normal and Abnormal. 364-390, Oxford Univ Press, New York, 1993.

5 ) Mitsui Y: The magician's forceps phenomenon. In Strabismus and the sensorimotor reflex. 3-17, Excerpta Medica, Amsterdam, 1986.

6) Adler FH : Pathologic physiology of strabismus. Arch Ophthalmol 48:19-29, 1953.

7 ) Jampolsky A : What can electromyography do for the ophthalmologist? Invest Ophthalmol Vis Sci 9:570-599, 1970.

8 ) Von Noorden: Principles of surgical treatment. In Binocular Vision and Ocular Motility $4^{\text {th }}$ ed. 479 , Mosby, St. Louis, 1990. 